\title{
FinTech in Latvia: Status Quo, Current Developments, and Challenges Ahead
}

\author{
Ramona Rupeika-Apoga ${ }^{1, *(1)}$ and Stefan Wendt ${ }^{2}$ (D) \\ 1 Faculty of Business, Management and Economics, University of Latvia, LV-1586 Rīga, Latvia \\ 2 Bifröst University, 311 Bifröst, Iceland; stefanwendt@bifrost.is \\ * Correspondence: rr@lu.lv
}

Citation: Rupeika-Apoga, Ramona, and Stefan Wendt. 2021. FinTech in Latvia: Status Quo, Current Developments, and Challenges Ahead. Risks 9: 181. https:// doi.org/10.3390/risks9100181

Academic Editor: Mogens Steffensen

Received: 30 July 2021

Accepted: 9 October 2021

Published: 14 October 2021

Publisher's Note: MDPI stays neutral with regard to jurisdictional claims in published maps and institutional affiliations.

Copyright: (c) 2021 by the authors. Licensee MDPI, Basel, Switzerland. This article is an open access article distributed under the terms and conditions of the Creative Commons Attribution (CC BY) license (https:// creativecommons.org/licenses/by/ $4.0 /)$.

\begin{abstract}
FinTech has been in the focus of discussion for quite some time. However, the market share of FinTech companies is still relatively small compared to that of more traditional financial services. The purpose of this paper is to analyse the status quo, current developments, and challenges ahead for the Latvian FinTech sector. We combine three analyses: a political and legal, economic, social, and technological environment (PEST) analysis; a survey among FinTech companies; and an analysis of the size and financial performance of FinTech companies during the last 10 years. We find that the current status of regulation is one of the main obstacles to FinTech development, because it does not sufficiently consider FinTech-specific aspects. Problems in attracting a skilled workforce and an environment that is not very supportive of new developments in finance are further challenges and might explain at least part of the growth and financial performance difficulties. A revision, modernization, and harmonization of regulation is essential to create a level playing field for all market participants: FinTech companies, traditional financial service providers, and those originally traditional players that are integrating FinTech solutions in their business model. Further efforts are also required to foster Latvia's attractiveness for a skilled workforce. We hope that this study helps increase the visibility of Latvian FinTech and contributes to the development of the new Latvian FinTech strategy.
\end{abstract}

Keywords: FinTech; financial markets; PEST analysis; survey analysis

\section{Introduction}

FinTech has been in the focus of the discussion in the financial industry, in politics and regulation and in academic research for quite some time. However, even though FinTech has often been labelled a disruption to the financial industry (Gomber et al. 2018; Laidroo et al. 2021a), the market share of FinTech companies is still relatively small in most areas compared to more traditional financial services (IMF 2019). Definitions of FinTech cover both the application of new technologies to financial services and corresponding new business models, processes, and products. According to OECD (2018), "FinTech involves not only the application of new digital technologies to financial services but also the development of business models and products which rely on these technologies and more generally on digital platforms and processes". Similarly, the Financial Stability Financial Stability Board (2019) defines FinTech as "technology-enabled innovation in financial services that could result in new business models, applications, processes or products with an associated material effect on the provision of financial services".

For our study of FinTech companies in Latvia, we use the definition provided by the Bank of Latvia in line with the definitions by the OECD and the Financial Stability Board: a FinTech company is "a company which develops and uses new and innovative technologies in the area of financial services. This leads to the development of new financial products and services or a significant improvement of the existing ones" (Bank of Latvia 2020). This definition also reflects the EU Parliament's definition, according to which FinTech should 
be understood "as finance enabled by or provided via new technologies, covering the whole range of financial services, products and infrastructure" (The European Parliament 2017). FinTech companies in Latvia provide services that are complementary to traditional financial services, but also services that represent (potential) substitutes for services covered by traditional financial service providers. Therefore, the development of FinTech increases competition in markets for financial services. It is worth mentioning, though, that FinTech development is not limited to pure FinTech companies. Traditional financial service providers have also made increasing efforts to integrate FinTech solutions into their business models, which means that it is not fully possible to consider FinTech completely separately from more traditional financial service providers.

The success of FinTech development depends on, e.g., access to finance and human resources and the attitude of regulators, in particular with regard to openness to innovation and flexibility (Rupeika-Apoga and Thalassinos 2020). Additionally, the risks for potential and actual clients (Horn et al. 2020) and trust in financial services play important roles (Oehler and Wendt 2018). In Latvia, FinTech development meets well developed financial market infrastructure as well as a highly skilled workforce with relatively high entrepreneurial ability. Additionally, Latvia is internationally highly ranked in the context of the information and communications technology (ICT) development, showing strong positions in Internet subscriptions, electricity access, and supply quality, and the percentage of Internet users among the adult population (World Economic Forum 2019, 2020). Depending on their specific activities, FinTech companies are regulated and monitored by the Latvian Financial and Capital Market Commission (FCMC 2021a), the Consumer Protection Center (CRPC), or the State Revenue Service. FinTech-specific legislation is not existent in Latvia, though. Additionally, Latvia has a much more detailed and rigorous approach to customer due diligence than other countries (Saksonova and Koleda 2017), which affects FinTech companies as customers of Latvian banks, and in cases where FinTech companies want to obtain an FCMC license to provide their service.

Despite the publication of some market factsheets, e.g., by the commercial bank Swedbank (Swedbank 2020) and Fintech News Baltic blogs (FinTech Baltic 2020), a comprehensive understanding of the main drivers of the development of FinTech companies in Latvia has not yet been achieved. The purpose of this study is to add to this understanding, to shed light on the status quo, current developments, and challenges ahead for the Latvian FinTech sector, and to develop suggestions on how to foster FinTech development in Latvia.

To achieve the purpose of this study, we combine three analyses: first, we perform an analysis of the political and legal, economic, social, and technological environment (PEST analysis) that FinTech companies are facing in Latvia. Second, we analyse these companies' responses to a survey with particular emphasis on their own assessment of current and potential future developments. Third, we analyse the size and financial performance of FinTech companies in Latvia during the last 10 years.

Our contribution to the academic literature and the public and political debate is four-fold. First, with its focus on the environment Latvian FinTech companies are facing, their own assessment of various drivers and obstacles of FinTech development, and their actual size and financial performance, we substantially contribute to a comprehensive understanding of the complex topic of FinTech development in Latvia. Improving such an understanding will also help raise awareness for FinTech in Latvia.

Second, based on the results of our analyses, we discuss suggestions on how to support FinTech development in Latvia. These suggestions might be of particular interest for FinTech companies, for traditional financial service providers, and for policy makers and regulators.

Third, the current research assists in the development of the new Latvian FinTech strategy by providing findings based on the results of the FinTech Survey. This paper helps policymakers to understand the main obstacles and challenges in the development of the FinTech market. The new policy is expected to be finalised by 31 October 2021. 
Fourth, the findings of this study also provide implications beyond Latvia. Latvia is a small country with a small market, which might not necessarily appear of particular importance on a global scale or when it comes to international comparison in the context of FinTech. However, when it comes to FinTech, the small size of a country is not necessarily a disadvantage. As part of the Global Fintech Index City Rankings report 2020, Findexable (2019) ranks Latvia's immediate neighbours Lithuania and Estonia fourth and tenth, respectively, in its global FinTech country rankings. According to the Fintech News Network, Latvia, Zimbabwe, and Israel have witnessed the highest surge in FinTech interest worldwide in 2021 (FinTech Baltic 2021). Hence, our findings for Latvia can also be relevant to other small countries, such as Lithuania, Estonia, Malta, Belarus, Gibraltar, and others.

We find that the current status of regulation is one of the main obstacles to FinTech development. This is reflected in both the PEST analysis and the responses to the survey. The regulation currently does not sufficiently consider FinTech-specific aspects. A revision, modernization, and harmonization of regulation in particular across different categories of financial services, across different types of companies/institutions providing these services, irrespective of a higher or lower degree of involvement of new technologies, and internationally would truly provide a level playing field for all market participants: FinTech companies, traditional financial service providers, and those originally traditional players that are integrating FinTech solutions in their business model. Comprehensive regulation would also correspond to our finding that FinTech companies see themselves less in a disruptive role, but they emphasise partnership with traditional banks and that traditional financial service providers will integrate new technology. The size and financial performance of FinTech companies in Latvia during the last ten years indicates some difficulties when it comes to growth and when it comes to establishing and maintaining business models that are financially sustainable. Problems in attracting a skilled workforce and an environment that is not very supportive of new developments in finance are further challenges and might explain at least part of the growth and financial performance difficulties. Hence, further efforts are required to foster Latvia's attractiveness for a skilled workforce.

The structure of this paper is as follows. The next section, Section 2, focuses on the data and methodology. Section 3 uses a PEST analysis framework to investigate the environment that the Latvian FinTech companies are facing. Section 4 presents and discusses these companies' responses to a survey with particular emphasis on their own assessment of current and potential future developments. Subsequently, Section 5 provides an overview of the financial performance of a number of FinTech companies in Latvia during the last 10 years. Section 6 discusses the findings and concludes.

\section{Data and Methodology}

The PEST analysis uses desk research methodology, also including the analysis of corresponding regulation. To identify potential survey participants and to be able to analyse size and financial performance, we needed to identify FinTech companies that are registered in Latvia, because there is no official list of such companies. Neither the Latvian central bank, nor the FCMC, nor the Ministries of Finance and Economics provide a list of FinTech companies. The only available FinTech landscapes are provided by FinTech FinTech Baltic (2020) and Swedbank (2020). The Fintech Latvia Startup Map 2020 consists of 50 FinTech startups (FinTech Baltic 2020). According to the Latvian FinTech Report 2020 prepared by Swedbank in cooperation with Startin, however, the number of FinTech companies in 2019 was 75, and in 2020, it reached 91 (Swedbank 2020).

Difficulties in classifying FinTech companies relate to the emergence of new business models, which make it difficult to gather a comprehensive list. While we use the definition of FinTech provided by the Bank of Latvia, this definition also captures traditional financial service providers using new and innovative technologies. To help identify FinTech compa- 
nies, a company's business model and operations must reflect the definition and fall into at least one of the following seven areas:

- Analytics - data mining, data (business) analytics, big data analysis, machine learning, artificial intelligence used for automated advice, chatbots, customer relations management, and data handling.

- Banking infrastructure-user interface, processing enhancement, technology infrastructure, various trading platforms, and software companies with a focus on the financial sector.

- Deposit and Lending — crowd investing, crowdlending, invoice trading, and other lending forms such as payday loans.

- Distributed Ledger Technology—cryptocurrency and everything encompassing blockchain technology, even from companies that are payment or crowdfunding companies at the same time.

- Insurance-insurance-related products and services and InsurTech.

- Payments-mobile payments, online payments, money transfers, and anything related to payments.

- Investment management-online investment processes based on algorithms and models, robo-advisors, and social trading.

This classification is similar to the one used in the IFZ FinTech Study 2018 (Ankenbrand et al. 2019) and the FinTech Report Estonia 2019 (Tirmaste et al. 2019).

To find companies to be included in our analysis, we identified companies listed as FinTech companies in the Crunchbase, a platform for finding business information about private and public companies (Crunchbase 2020) and checked whether these companies fell under our definition. Then, we added FinTech companies found from other data sources: Key Capital for Latvia (Key Capital 2020), Alternative Financial Services Association of Latvia (The Alternative Financial Services Association of Latvia 2021), and Investment and Development Agency of Latvia (Investment and Development Agency of Latvia 2020). Additionally, the list of FinTech companies was cross-checked against the Register of Enterprises of the Republic of Latvia to ensure that only FinTech companies incorporated in Latvia are considered. This differs from the FinTech lists provided by FinTech Baltic and SwedBank, as they also include companies registered in other countries but operating in Latvia. In 2019, we identified 66 companies that meet our criteria. However, during the preparation of the paper, some companies were dissolved due to mergers or acquisitions, changed countries of registration, or were in the liquidation process. As a result, 56 companies were selected for inclusion in the dataset. As the definition of FinTech is controversial, and as the FinTech sector is rapidly evolving, we understand that our dataset can never be complete.

The survey questions were mainly based on the IFZ FinTech Study 2019 questionnaire (Ankenbrand et al. 2019) and the FinTech Report Estonia 2019 (Tirmaste et al. 2019) and were modified to assess the development of Latvian FinTech companies. The survey starts with general questions about the company, such as business model (B2B vs. B2C) and fields of activity, and questions on fields of activity, revenue model, and on some details of the operations. Then, the survey asks participants to rate a number of problem areas, such as competition, access to finance, and regulation, on how pressing they are on a scale from 1 (not pressing) to 10 (extremely pressing). ${ }^{1}$ The final section of the survey includes questions on the current and expected future relationship between FinTech and traditional banking and between FinTech and the Latvian state, on the main triggers of FinTech development and the role of regulation. Most of the questions in this section of the survey were open-ended questions; for a few questions, some predefined response items were included but were always accompanied by an open-ended response option. The results section will provide more details on the response items.

The survey was conducted as an online survey in the summer of 2019. Links to the online questionnaire (on Google docs) were sent via email to the 56 companies identified as FinTech companies. Corresponding email addresses were determined based on data 
presented in local business registries or companies' webpages or found through personal contacts. If possible, the email was targeted directly to the company's owners, board members, or executives (e.g., CEO, CFO). In the remaining cases, it was sent to the company's general email address. The first email was followed by two to three reminders. In some cases, follow-up phone calls and instant messaging through social media were also used to increase the response rate. Local institutions helped also by spreading the word about the survey, and news sites were used for the same purpose. We received a total of 21 responses, which corresponds to a response rate of 37.5 percent, but it also means that 62.5 percent did not respond. Even though the number of responses does not allow detailed statistical analysis, the response rate can be considered satisfactory for this type of survey (Hoque 2004; Olson and Slater 2002; Rikhardsson et al. 2020).

In addition, and to examine the latest trends in the development of FinTech companies in Latvia, we collected size and financial performance measures for the FinTech companies that responded to the survey from Bureau van Dijk's Orbis database (Bureau van Dijk 2021) for the period from 2010 to 2019. As size measures, we include the number of employees, turnover, and total assets; as financial performance measures, we include return on equity (RoE) and profit margin. Given the low number of companies, we abstain from detailed statistical analysis but provide corresponding descriptive statistics instead. Even though using data for these companies instead of all FinTech companies in Latvia might bias our results to some degree, using the smaller sample of companies that responded to the survey allows us to discuss the size and financial performance development and the responses to the survey jointly.

Another challenge is the increasing number of FinTech companies over time. This means that we do not have data for all companies across the entire period from 2010 to 2019. Additionally, in very few cases, data points are missing. This means that results from comparing between years need to be interpreted with caution, in particular because new market entries are typically smaller than already established companies.

\section{The Latvian FinTech Environment}

To provide a thorough overview of the Latvian FinTech environment, we analyse the political and legal, economic, social, and technological environment (PEST analysis) (Sammut-Bonnici and Galea 2015). This analysis of the environment FinTech companies are facing in Latvia is essential to be able to understand the status and development of FinTech in Latvia.

The analysis of the political and legal environment is of importance due to increased competition between cities and, in particular, countries to become FinTech centres or hubs. Taking into account the experience of other countries, regulation can be an effective tool in stimulating innovation and economic development. Differences in the legal environment can lead to regulatory arbitrage between different jurisdictions (Rupeika-Apoga and Thalassinos 2020). Combining this thought with differences in political support or goodwill can even lead to regulatory/politically induced arbitrage within the same jurisdiction between cities or regions with different political situations (Ito et al. 2020). Eventually, this can trigger a race to the bottom between jurisdictions in deregulating the legal environment and/or an escalation in political and potential financial support to attract or keep FinTech companies. This becomes even more interesting when considering that relatively similar business models might be categorized quite differently depending on whether corresponding products and services are offered by traditional financial intermediaries or by FinTech companies and even depending on different types of FinTech companies (Tirmaste et al. 2019).

The economic environment refers to external economic factors that affect the economy, e.g., purchasing habits of consumers/customers and businesses, and therefore affect aspects such as actual and potential market size and development, entrepreneurial activity, and performance of FinTech companies. Customer purchasing power, taxes, unemployment, and many other economic factors can promote or hinder the development of FinTech 
companies (Filimonova et al. 2020). The PEST analysis helps us assess how favourable the economic environment is in Latvia compared to neighbouring countries and Europe.

FinTech companies, as with any other company, operate in a society, while each society constructs its own social environment. The main factors affecting the social environment, and hence, FinTech companies also include, e.g., the educational system and literacy level, attitudes towards innovative products, lifestyle, occupational distribution and consumer preferences, labour force expectations, consumption habits, and social inequality (Kluza et al. 2021). FinTech companies must be aware of the social preferences of society in relation to its needs and desires, and they must adapt to the social environment in which they operate in order to be competitive.

The technological environment includes forces associated with scientific improvement and innovation that provide new ways of producing goods and services, as well as new methods and techniques for conducting business (Saksonova 2014). FinTech is inherently connected with technological development. In order to study the current situation and development of the Latvian FinTech sector, it is necessary to analyse aspects such as the pace of technological progress and institutional mechanisms for the development and application of new technologies, to name a few.

\subsection{Political and Legal Environment}

3.1.1. EU Regulatory Framework

As Latvia has been a member of the European Union (EU) since 2004, EU regulation provides the main regulatory framework. In 2018, the European Commission adopted the FinTech action plan for the development of a more competitive and innovative financial sector in Europe with the main purpose of increasing supervisory convergence toward technological innovation and to allow the EU financial sector to benefit from new technologies (The European Commission 2018). Not only is the purpose to build a capital markets union but also a digital single market for consumer financial services in order to allow innovative products and solutions to spread quickly across the EU. One of the purposes is to prevent regulatory arbitrage between the legal statuses, legislation, and supervision in the member states. EU regulation focuses on the application of the same rules to the same services and the same risks regardless of the type of legal entity concerned or its location in the Union, technology neutrality and a risk-based approach, taking into account the proportionality of legislative and supervisory actions to risks and materiality of risks (The European Parliament 2017).

Latvia has implemented European regulation on a number of aspects that also relate to FinTech. Implemented directives include the Payment Services Directive (PSD2) (The European Parliament and of the Council 2015), the Directive on the prevention of the use of the financial system for the purposes of a Money Laundering and Terrorist Financing (AMLD5) (The European Parliament and of the Council 2018), the Markets in Financial Instruments Directive (MiFID-2) (The European Parliament and of the Council 2014), NearField Communication (NFC) (European Union 2009), and the Investment Firms Directive ((EU) 2019/2034) (IFD)) and the Investment Firms Regulation ((EU) 2019/2033)) (IFR) (The European Parliament and of the Council 2019b); the new Prospectus Regulation (Commission Delegated Regulation (EU) 2019/980) regarding the format, content, scrutiny, and approval of prospectuses has been published in the Official Journal (The European Commission 2019). However, Latvia's more detailed and rigorous approach to customer due diligence than other countries and higher compliance cost create challenges for FinTech companies as customers of Latvian banks and when obtaining an FCMC license.

In addition, in November 2021, a new regulation on European providers of crowdfunding services for businesses will enter into force. This regulation is part of the Commission's FinTech action plan with the aim of introducing a unified system across all EU member states to facilitate the provision of cross-border co-financing services (The European Parliament and of the Council 2020). 


\subsubsection{Latvian Regulatory Framework}

As there is no specific legislative framework for FinTech companies in Latvia, they have to obtain licenses that match their business models if they require licensing, such as deposit-taking, investment management, capital raising, issue of financial instruments, provision of payment or electronic money services, insurance, or provision of consumer credit services. The FCMC or the CRPC regulate and supervise FinTech companies, depending on their financial services. The main supervisor is FCMC, while CRPC is responsible for, e.g., consumer protection, market surveillance, and the safety of products and services.

The main market participants are credit institutions, credit unions, investment management companies, investment brokerage firms, alternative investment fund managers, insurance companies, payment institutions, private pension funds ${ }^{2}$, and electronic money institutions. All institutions are subject to national laws and regulations, including the licensing process. There is a broad variety of rules and regulations, which means that financial institutions are regulated very differently depending on the segment of the financial sector they are active in. Hence, the following overview cannot provide a complete picture of corresponding regulations but is intended to provide a brief idea of the regulatory framework. ${ }^{3}$

Credit institutions and credit unions (financial cooperatives) need to submit to the FCMC (The Financial and Capital Market Commission 2002) the corresponding application and documents to receive an operating licence (permit). The minimum initial capital for a credit institution is five million euros, while for credit unions, the minimum initial capital is 2500 euros, and the decision to issue a licence is adopted by the European Central Bank based on a draft proposal by FCMC. Regulation that applies to credit institutions includes, e.g., the Deposit Guarantee Law (The Parliament of the Republic of Latvia 2015a) and the Law on the Recovery and Resolution of Credit Institutions and Investment Firms (The Parliament of the Republic of Latvia 2017). Credit Unions are regulated by the Credit Union Law (The Parliament of the Republic of Latvia 2001a) and the Regulations on the State Fee for the Issue of a Special Permit (Licence) for Individual Types of Entrepreneurial Activity (Cabinet of Ministers 2011). FinTech companies that are only interested in offering consumer lending services are regulated by the Consumer Protection Act (The Parliament of the Republic of Latvia 1999) and monitored by the CRPC. These companies do not need a licence as a credit institution but should obtain a license from the CRPC, and their initial capital must be at least EUR 425,000.

Investment-related services are provided by investment management companies, investment brokerage firms (investment firms), and by alternative investment fund managers. Corresponding regulation includes, for investment management companies, e.g., the Law on the Investment Management Companies (The Parliament of the Republic of Latvia 1997), the Commercial Law (The Parliament of the Republic of Latvia 2000), and the Investor Protection Law (The Parliament of the Republic of Latvia 2001b). For investment firms, which provide investment and ancillary (non-core) services, such as brokerage, investment advice, portfolio management, and custody services, regulation includes, e.g., the Law on the Financial Instruments Market (The Parliament of the Republic of Latvia 2003) and the regulatory enactments of the FCMC, and potentially, regulation by the Latvian Central Depository. For alternative investment fund managers, the Law on Alternative Investment Funds and their Managers (The Parliament of the Republic of Latvia 2013), the FCMC normative acts, EU Regulations, the Commercial Law, and other regulatory enactments apply. An alternative investment fund manager can commence its activities after its registration with the FCMC (registered manager) or after the receipt of the corresponding license (licensed manager). Additionally, investment management companies and investment firms must apply for a licence from the FCMC. The minimum initial capital shall be EUR 125,000 for investment management companies. On 26 June 2021, most investment firms became subject to a new prudential framework, composed of Regulation (EU) 2019/2033 (The European Parliament and of the Council 2019c) and Directive (EU) 2019/2034 (The European Parliament and of the Council 2019a). A permanent minimum capital require- 
ment set in the regulation is EUR 75,000, EUR 150,000, or EUR 750,000, depending on the activities of the investment firm.

Insurance companies are regulated under the Law on Insurance and Reinsurance (The Parliament of the Republic of Latvia 2015b), the Compulsory Civil Liability Insurance of Owners of Motor Vehicles Law (The Parliament of the Republic of Latvia 2004), the Insurance Contract Law (The Parliament of the Republic of Latvia 2018), the Insurance and Reinsurance Distribution Law (The Parliament of the Republic of Latvia 2019), and the Law on Insurance and Reinsurance. If they intend to offer particular insurance classes (motor vehicle third-party liability insurance, aircraft or ship ownership liability insurance, general liability insurance, credit insurance, suretyship insurance, or life assurance), a minimum initial capital of EUR 3.7 million applies, in other cases, a minimum initial capital of EUR 2.5 million applies.

Institutions that offer payment services as specified in Article 1 (1) of the Law on Payment Services and Electronic Money (The Parliament of the Republic of Latvia 2010) need a licence from the FCMC. If a natural or legal person wishes to offer payment services but is not required to obtain a licence as a payment institution, it needs to be registered at the FCMC. The initial capital of a licensed payment institution must be at least EUR 20,000 if it provides only money remittance services, EUR 50,000 if it provides only the payment initiation services, and EUR 125,000 if it provides any of the payment services referred to in the above-mentioned Article 1 (1), Subparagraphs a, b, c, d, or e. No initial capital is required if it only provides an account information service. However, a payment institution that provides an account information service and/or a payment initiation service needs to have its professional civil liability insurance. Additionally, financial allowances for persons intending to provide only an innovative payment service, which requires the authorisation of a payment institution or electronic money institution, are described in the Law on Payment Services and Electronic Money.

Institutions that wish to issue electronic money need a licence from FCMC or-if they do not need a licence-need to be registered at the FCMC. These institutions are entitled to provide payment services in accordance with the Law on Payment Services and Electronic Money. The initial capital of a licensed electronic money institution shall be at least EUR 350,000 , also in the case that it additionally offers payment services (The Parliament of the Republic of Latvia 2010).

Even though some other services provided by FinTech companies might currently not need a licence from FCMC or CRPC, the regulatory framework for such innovative activities is evolving. Investment platforms, for example, need to obtain a licence from FCMC during the transition period. The State Revenue Service monitors cryptocurrencyrelated activities. Similar to regulators in other countries, the FCMC has launched a regulatory innovative sandbox and hub ${ }^{4}$ to allow testing of innovative financial services, such as a new or substantially improved electronic payment or electronic money services. The intention behind such a testing opportunity is to reveal whether or not the innovative financial service leads to one or more of the following improvements (FCMC 2021b):

- increased competition, i.e., is the innovative financial service more advantageous, less costly and easier to use than traditional services;

- potential response from traditional market participants, either by improving their service or by adopting the innovative business model;

- access for consumers and non-professional customers to market segments that have traditionally not been available to them.

\subsection{Economic Environment}

One of the preconditions for vibrant FinTech development is a well-developed economic environment. Since the general economic environment in a country, such as economic growth, economic policy, tax rates, ease of conducting business, and costs, affects FinTech businesses, FinTech companies-due to their high degree of international mobilityare typically located where the economic environment best meets their business needs. 
Low tax rates and local monetary policy (currency stability, interest rates) are typically considered as the most important factors.

According to a Global Financial Centres Index (GFCI) survey, the most important elements of a competitive environment for FinTech providers include the availability of skilled professionals and access to finance combined with big data analytics and cybersecurity as most important applications (Yeandle and Mainelli 2015). With regard to the level of development of the financial market infrastructure, there is a need for an efficient trading system and a variety of tradable financial instruments, such as stocks, bonds, and derivatives. Well-developed financial markets allow financing via traditional channels, such as stock exchanges or banks, or via alternative channels, such as crowdfunding, venture capital, or business angels. The efficiency of the payment system, its speed, and its security, also play important roles (Rupeika-Apoga and Nedovis 2016).

The World Bank World Bank Group's (2020) Doing Business Report ranks Latvia 19th among the 190 countries covered by the report (World Bank Group 2020). While that report draws a relatively positive picture for the overall business environment, the Global Financial Centres Index (GFCI) ranks the Latvian capital Riga in March 2020 only 70th out of 108 cities. While this rank is nearly the same as in 2016, when Riga ranked 71st, the city had climbed to rank 45 in the meantime and outperformed centres such as Stockholm (46th), Liechtenstein (48th), and Copenhagen (52nd) (Long Finance and Financial Centre Futures 2020; Solovjova et al. 2018). However, Riga could not maintain this position, mainly due to the major scandals related to the anti-money laundry (AML) processes, involving several Latvian banks.

On the Global Entrepreneurship Index, which measures the quality and dynamics of entrepreneurship ecosystems, Latvia ranked 45th out of 137 countries in 2019, which is lower than Latvia's neighbours Estonia (22nd) and Lithuania (37th). In the different subcategories, Latvia's rank ranged from 38th for entrepreneurial ability to 51st for entrepreneurial aspiration (Ács et al. 2019)

In the Findexable (2019) Global FinTech Index City Rankings 2020, Latvia ranks 49th out of 65 countries, with Riga ranking 34th among 50 leading European cities and 96th among 238 cities worldwide. Again, Latvia is outperformed by Lithuania (4th rank) and Estonia (10th rank) (Findexable 2019).

\subsection{Social Environment}

One of the main sources of FinTech competitiveness and development is a skilled and educated workforce (Rupeika-Apoga and Saksonova 2018). This relates to the local professional workforce, representing the majority of the workforce, and to a smaller number of international professionals, who follow and develop their business moving from country to country, as well as to the relationship between these two groups. FinTech development requires a highly skilled international workforce with deep and extensive knowledge and experience in financial and technology services. A large number of highly qualified potential local employees as result of, e.g., strong education policies combined with flexible labour legislation would allow companies to recruit and expand according to business needs. Attracting international professionals requires open and flexible immigration policies.

The IMD World Talent Ranking (Institute for Management Development 2019), which evaluates the extent to which economies develop, attract, and retain highly skilled professionals, ranks Latvia 12th in investment and development, 48th in appeal and 41st in readiness, resulting in an overall rank of 34th out of 63 countries. Latvia ranks particularly well when it comes to female labour force (2nd), government expenditure on education per student (7th), and pupil-teacher ratio in secondary education (9th). However, brain drain (50th), remuneration in services professions (51st), and effective personal income tax rate (47th) represent main obstacles.

In 2019, the Global Competitiveness Report (World Economic Forum 2019) ranked Latvia 22nd regarding skills, but only 100th out of 141 countries regarding ease of finding a 
skilled workforce. Overall, Latvia ranks 28th regarding the labour market, with favourable conditions in wage flexibility (10th) and workers' rights (26th), but low scores in ease of hiring foreign labour (113th) and labour tax rate (114th). Further, the Europe 2020 Competitiveness Report (World Economic Forum 2020) ranks Latvia 5th in labour market and employment but only 22nd in education and training and 25th in social inclusion.

\subsection{Technological Environment}

The World Economic World Economic Forum (2019) ranks Latvia 15th out of 141 countries when it comes to information and communication technology (ICT) adoption, with a particularly strong position in mobile-broadband and fibre internet subscriptions (12th), even though Latvia only ranks 32nd regarding Internet users within the adult population. Moreover, electricity access is excellent (2nd), while electricity supply quality (34th) and digital skills among the active population (39th) still need improvement (World Economic Forum 2019).

However, out of 27 European countries, Latvia ranks only 20th in digital agenda and 24th in Innovative Europe index, significantly lagging behind its neighbours Estonia (5th in digital agenda and 12th in Innovative Europe), and Lithuania (11th in digital agenda and 21st in Innovative Europe) according to the Europe 2020 Competitiveness Report (World Economic Forum 2020).

\section{Survey Results}

This section presents the main findings of the survey. We start with a general portrait of the responding FinTech companies and then link the survey to the PEST factors (political and legal, economic, social and technological environment).

\subsection{General Portrait of the Responding FinTech Companies}

In total, 21 out of 56 FinTech companies responded to the survey. The distribution of the companies by their activity type is presented in Figure 1.

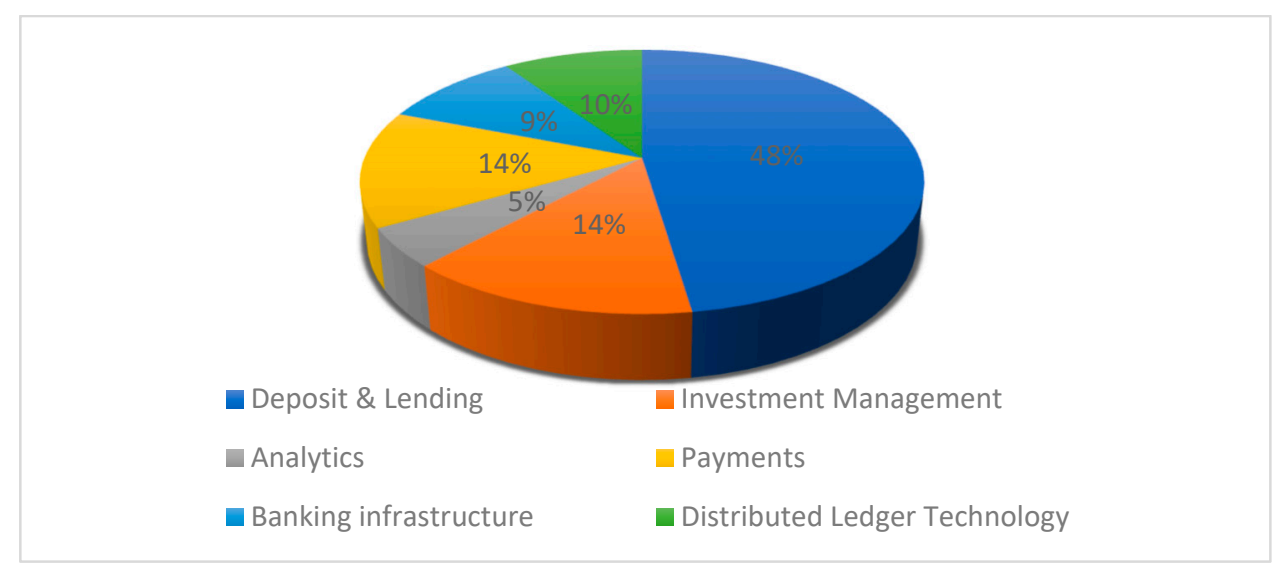

Figure 1. Breakdown of the responding FinTech companies by their field of activity.

Ten of the respondents stated their core field of activity as deposit and lending, three stated payments, and three stated investment management or investment brokerage. Two stated distributed ledger technology, one analytics, payments, transaction processing, and public finance management, and two stated analytics and banking infrastructure. This means that, even though deposit and lending represents the largest group, the group of respondents is quite diverse and includes representatives of most of the essential areas of FinTech activity. The attractiveness of deposits and lending as a FinTech business model can be explained by the fact that Latvians typically borrow during periods when there is an unforeseen need for additional financial resources, and most of these borrowers are young people (Rupeika-Apoga and Saksonova 2018). This group of customers might not 
be particularly appealing for traditional banks, which largely leave this part of the market to FinTech companies.

Most of the respondents follow the B2C business model providing their services to individual clients $(81 \%)$, focusing on both the Latvian market and international clients. About one-fourth of the FinTech companies work with both individual clients and other businesses. Even though the FinTech companies see the greatest business potential in the Baltic and Scandinavian markets, the geographical distribution of their activities includes the EU countries, the Americas, as well as the countries of the Commonwealth of Independent States, Australia and New Zealand. So far, only a few companies are active in Asia.

The connection between FinTech companies' main activity and their revenue sources (Laidroo et al. 2021a) is also obvious in our sample (see Figure 2). Since the main activity of the surveyed companies is deposits and lending, their main income comes from commission payments and interest income. Other revenue sources, such as license fees, centralized hosting of business applications, trading income, data, advertising income, or other play a minor role or no role at all.

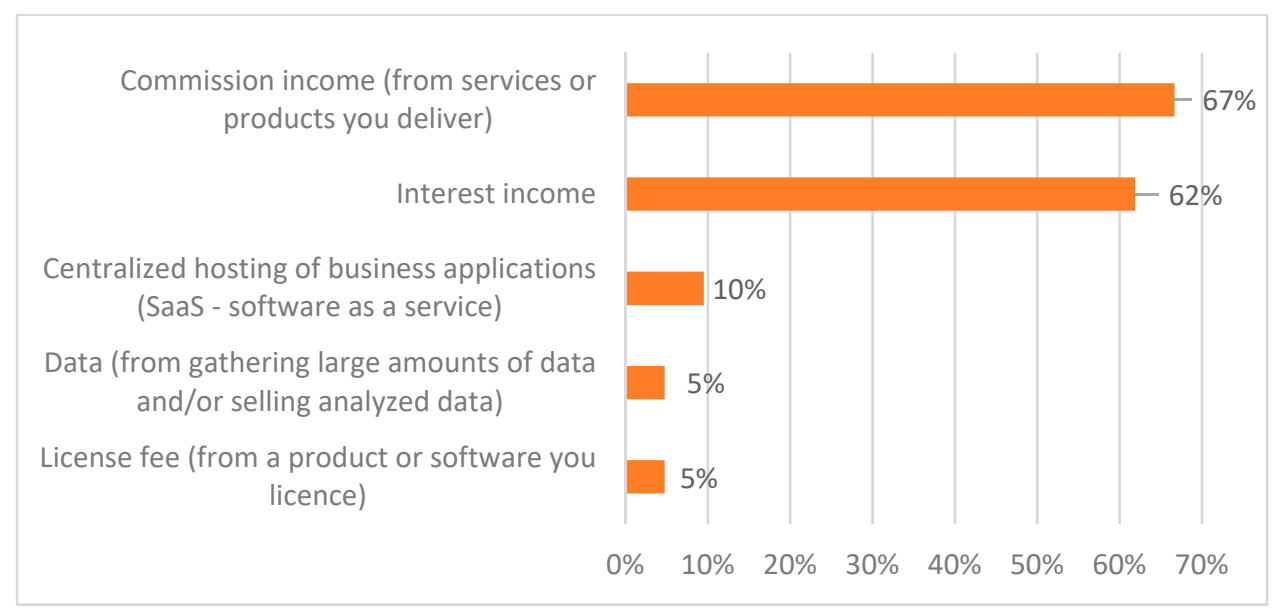

Figure 2. Revenue model (multiple responses allowed).

To finance their activities, FinTech companies primarily depend on their founders (16 out of the 21 respondents), followed by crowdfunding (six), venture capital (five), issuing securities (four), and business angels (three). Only two respondents indicate funding via retained earnings, and two indicate banks as source of funding (see Figure 3).

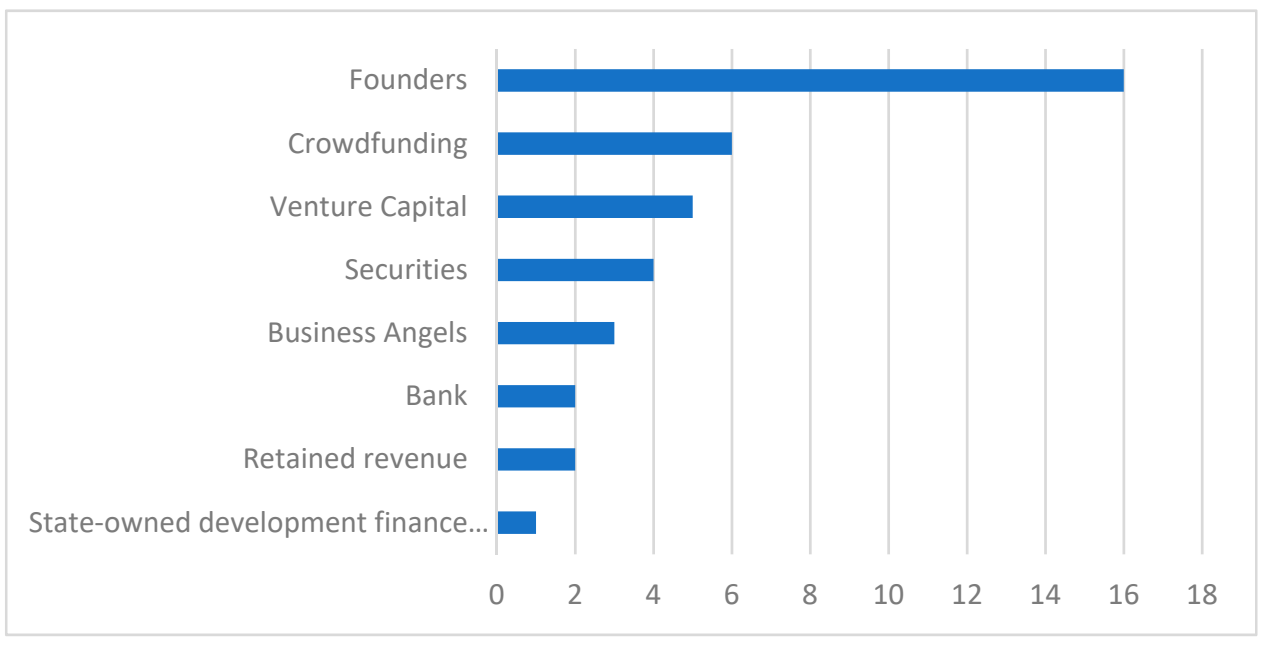

Figure 3. Sources of funding, number of FinTech (multiple responses allowed). 


\subsection{Assessment of Development Prospects for FinTech Companies}

In this section, we investigate the FinTech companies' responses with regard to the impact of the political and legal, economic, social, and technological environment on their competitiveness and potential future development. This means that the results in this section complement the PEST analysis presented in Section 3.

With regard to the economic environment, in particular the competitive environment, FinTech companies were asked to name their main competitors. Mostly, they mentioned other FinTech companies providing services in the same field, as well as traditional service providers such as banks and non-financial sector companies such as IT companies.

They were also asked to evaluate their situation relative to their competitors based on profit margin, fixed costs to assets, ability to scale, innovativeness, ease of compliance, and customer costs on a Likert scale from 1 to 7; the anchors of the seven-point scale differ between the items and are further explained below. The responses with regard to ease of compliance provide indication of their assessment of the legal and regulatory framework, profit margin, fixed costs to assets, and customer costs, representing economic factors. Ability to scale describes the ability to respond to an increasing or expanding workload or volume, reflecting the social and economic factors. The question how innovative the respondents are reflects social and technical factors. Figure 4 presents the corresponding findings.

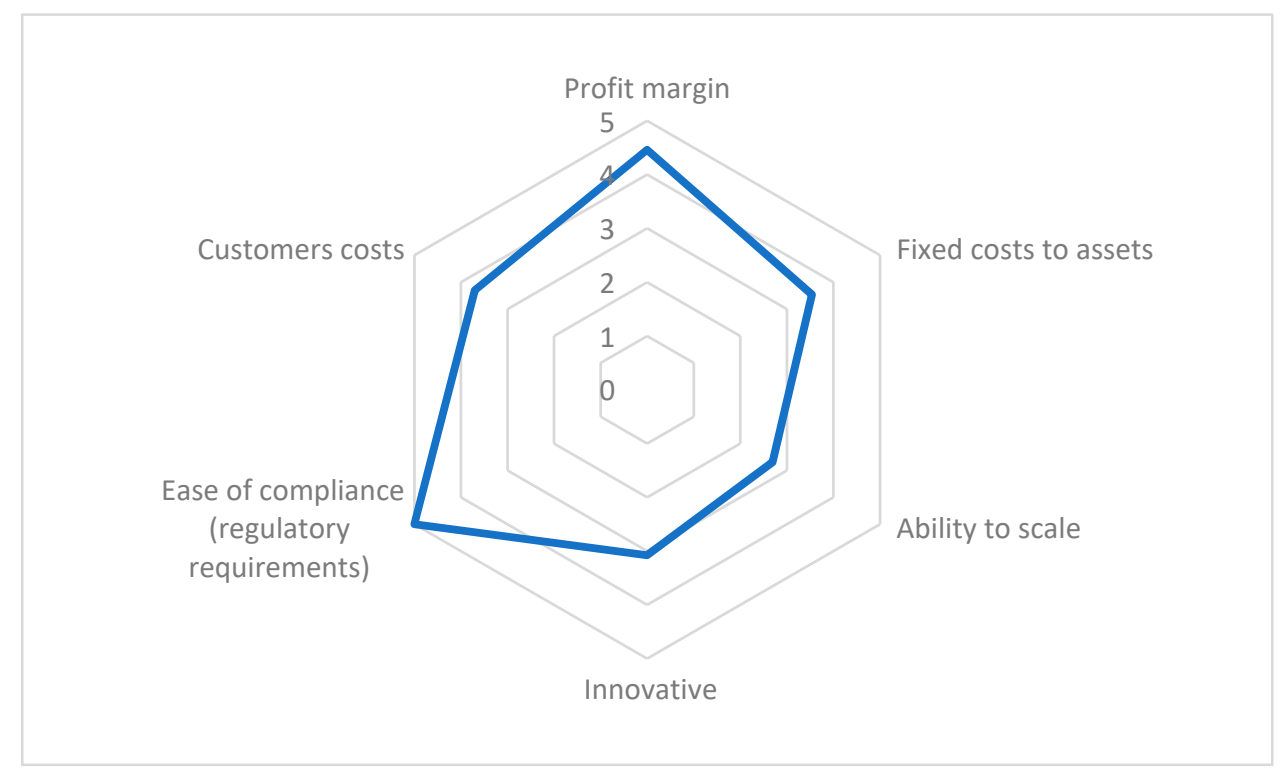

Figure 4. Responses to the request to evaluate the FinTech company against competitors; $1=$ low, 7 = high (means).

Ease of compliance with regulatory requirements is assessed on the scale from " 1 , not subject to high compliance regimes" to " 7 , subject to very high compliance regimes". The responses have an average value of 5 . Even though we did not specifically label the middle of the scale, this means the value of 4 represents being in a similar situation as the competitors; we interpret these responses as indication that the FinTech companies feel themselves as being under a stricter compliance regime than the competitors. Profit margin (on a scale from "1, very low" to "7, very high") has an average response of 4.5 , which is slightly above the middle of the scale. The companies might therefore see their business as slightly more profitable than their competitors. Fixed costs to assets and Customer costs, each on a scale from " 1 , very low costs" to "7, very high costs", receive average responses of 3.5 and 3.7, respectively. This means that they assess their costs as similar or slightly below their competitors" costs. Ability to scale (on a scale from "1, very scalable" to " 7 , not scalable") has an average response value of 2.7, which indicates that the respondents consider their activities as being more scalable than the activities of their competitors. 
On a scale from " 1 , very innovative" to " 7 , not innovative", the respondents assess their innovativeness with an average value of 3.1, which would reflect higher innovativeness than the competitors.

Even though FinTech is often considered disruptive of traditional financial services (Gomber et al. 2018), the survey responses to the questions of how FinTech companies will change traditional banks, as presented in Table 1, leave a different impression. Nineteen of the 21 respondents expect that FinTech companies will be partners of traditional banks, and sixteen respondents expect that traditional banks will adopt new technologies, modernize, and digitalize. Still, nine respondents also expect that customer ownership will be with FinTech companies, while traditional banks will become commoditized service providers. Only three respondents assume that traditional banks will not survive, and one respondent expects that traditional banks will become irrelevant.

Table 1. Responses to the question how the FinTech companies will change traditional banks (multiple responses allowed).

\begin{tabular}{ll}
\hline \multicolumn{1}{c}{ Response Items } & Number of Responses \\
\hline Pre-defined items & 16 \\
\hline $\begin{array}{l}\text { Traditional banks will adopt new technologies, modernize } \\
\text { and digitalize. }\end{array}$ & 3 \\
\hline $\begin{array}{l}\text { Traditional banks will not survive and will be replaced by } \\
\text { new technology-driven banks. }\end{array}$ & 19 \\
\hline FinTech companies will be partners of traditional banks. & 9 \\
\hline $\begin{array}{l}\text { Traditional banks will become commoditized service } \\
\text { providers, leaving customer ownership to FinTech } \\
\text { companies. }\end{array}$ & 1 \\
\hline $\begin{array}{l}\text { Traditional banks will become irrelevant as customers } \\
\text { interact directly with individual financial services providers } \\
\text { (FinTech). }\end{array}$ & 1 \\
\hline Other responses & 1 \\
\hline Traditional banks will not save retail and SME business. & \\
\hline $\begin{array}{l}\text { Situation will vary from market to market, thus so many } \\
\text { scenarios are selected. }\end{array}$
\end{tabular}

Exploring further the potential cooperation between FinTech companies and traditional banks, we specifically asked the open-ended question of how the respondent's FinTech company has cooperated with traditional banks. The answers reflect the variety of FinTech business models among our respondents. The cooperation ranges from the use of banking services, such as bank account services, daily payments or transfers, and funding opportunities, to client/customer identification and exchange, providing analytics and other services to banks, $\mathrm{API}^{5}$ access to banking infrastructure, credit card acquisition and payment innovations, and promotion of the financial industries.

We also asked in an open-ended question what the main triggers behind FinTech development are. Six respondents mentioned IT/technology development/digitalisation, changes in technological opportunities or innovation as main triggers. This underlines the importance of the technology factor, as explained in the PEST analysis. Additionally, strong customer focus is reflected in several responses that see customer mind-set and expectations, customer needs, and customer centric products as main triggers, reflecting the impact of social factors on the development of the FinTech industry. However, six respondents also see the regulatory framework as the main trigger.

One respondent elaborates:

Fintech embraces inclusiveness of financial services within different areas and allows to create targeted solutions for customers to try out without changing their bank. Incum- 
bents have failed in both innovation and communication, thus creating space for new players. As well-payment services directives are a significant trigger for increase of competition.

Further, respondents mentioned the economic and business environment, bank charges and outdated banks, qualified human resources and talents, access to capital, and start-up incubators as main triggers for FinTech development.

When asked about how pressing specific predefined problems are on a scale from 1 (not pressing) to 10 (extremely pressing), the respondents answered as shown in Table 2 and Figure 5. When considering the median values, regulation is the most pressing problem (median: 8), followed by availability of skilled staff or experienced managers (median: 7). Competition, finding customers, and access to finance rank third, with a median of 6 for each of these three categories. Cost of production or labour and expansion to international markets are relatively speaking less pressing (median: 5 ). When considering the distribution of the responses, however, it also becomes obvious that agreement among respondents about how pressing the given problems are is low, in particular with regard to access to finance and competition. A relatively low level of variation is apparent for, e.g., cost of production or labour.

Table 2. Responses to the question how pressing specific problems are; $1=$ not pressing, $10=$ extremely pressing.

\begin{tabular}{cccccccccccccccc}
\hline Level of How Pressing & $\mathbf{1}$ & $\mathbf{2}$ & $\mathbf{3}$ & $\mathbf{4}$ & $\mathbf{5}$ & $\mathbf{6}$ & $\mathbf{7}$ & $\mathbf{8}$ & $\mathbf{9}$ & $\mathbf{1 0}$ & $\mathbf{N}$ & Median \\
\hline Number of responses to predefined items & & & & & & & & & & & \\
\hline Competition & 2 & 0 & 1 & 2 & 2 & 6 & 5 & 1 & 1 & 1 & 21 & 6 \\
\hline Finding customers & 0 & 1 & 3 & 1 & 2 & 4 & 5 & 3 & 2 & 0 & 21 & 6 \\
\hline $\begin{array}{c}\text { Access to finance } \\
\text { Cost of production or labour }\end{array}$ & 2 & 2 & 3 & 1 & 1 & 2 & 5 & 2 & 1 & 2 & 21 & 6 \\
\hline $\begin{array}{c}\text { Availability of skilled staff or experienced } \\
\text { managers }\end{array}$ & 0 & 0 & 5 & 1 & 2 & 2 & 4 & 6 & 1 & 0 & 21 & 7 \\
\hline Regulation & 0 & 1 & 3 & 0 & 2 & 1 & 0 & 6 & 5 & 3 & 21 \\
\hline Expansion to international markets & 0 & 1 & 3 & 4 & 3 & 2 & 3 & 3 & 0 & 1 & 20 & 5 \\
\hline Other & 1 & 0 & 0 & 0 & 0 & 0 & 0 & 0 & 0 & 0 & 1 \\
\hline
\end{tabular}

The responses to the question how the Latvian state could contribute to the FinTech sector development as presented in Table 3 confirm the request for special regulation for FinTech companies (sixteen responses). Additionally, eleven respondents saw regulatory sandboxes as meaningful contributions, and seven respondents considered tax relief important. Although the predefined response items only focus on a limited range of potential government support, none of the respondents suggested further government support options.

Table 3. Responses to the question how the Latvian state could contribute to the FinTech sector development (multiple responses allowed).

\begin{tabular}{cc}
\hline Response Items & Number of Responses \\
\hline Predefined items & 16 \\
\hline Special regulations. & 11 \\
\hline Regulatory sandboxes. & 7 \\
\hline Tax relief. & 1 \\
\hline Other responses & \\
\hline Mostly none. &
\end{tabular}




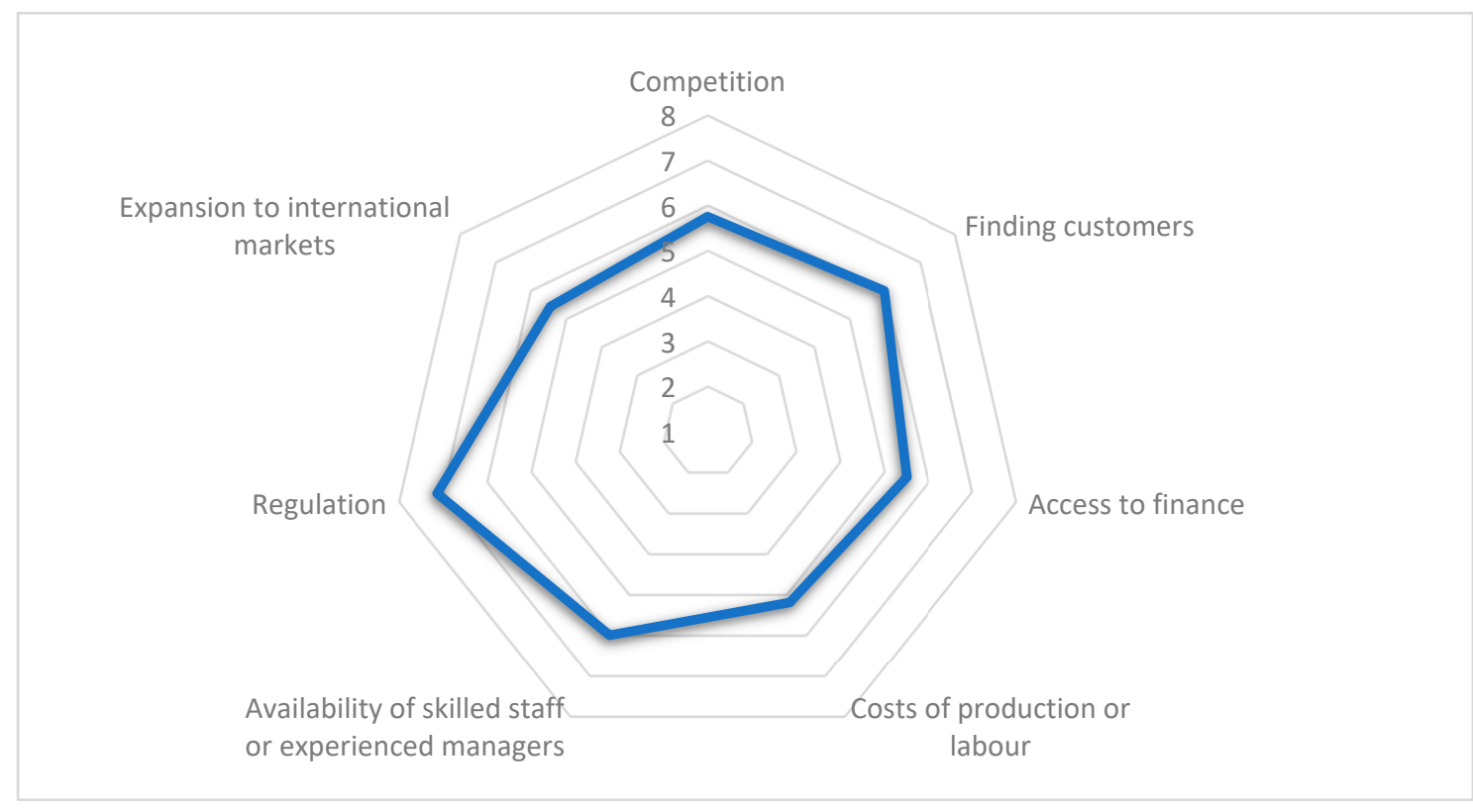

Figure 5. Responses to the question how pressing specific problems are; $1=$ not pressing, $10=$ extremely pressing (means).

The request for special regulation for FinTech companies is also reflected in the responses to the open-ended question if participants feel that existing financial service regulations are restricting their activities and-if yes-in what way. Only three of the sixteen responses indicate that financial service regulations are not restricting their activities. Twelve respondents answer that financial service regulations are restricting their activities. They elaborate on this by mentioning, e.g.,

There is no $100 \%$ relevant regulation for our specific business.

or

They try to box all new innovations in existing framework which mostly does not work.

Several respondents also mention the loan price limit from 1 July 2019 on, which is, in their opinion, not in alignment with the cost of capital of non-bank lenders.

However, FinTech companies who responded to our survey are in regular communication with state organizations (see Table 4). Communication with the State Revenue Service and the FCMC are mentioned most frequently, with twelve and eleven responses, respectively. Even though not included in the predefined response items, nine respondents mention, in the open-ended part of the question, the Consumer Rights Protection Center as an organization with which they regularly communicate. Only single respondents mention other organizations, such as the Bank of Latvia or the Ministry of Economics.

Overall, regulation and availability of skilled staff and experienced managers are the most pressing issues for Latvian FinTechs companies. Due to the supervisory status granted by the Committee of Experts on the Evaluation of Anti-Money Laundering Measures and the Financing of Terrorism (MONEYVAL) in 2018, supervision of the financial sector has become much more detailed and rigorous compared to other EU countries. To provide services, the FinTech company needs to have an account with a commercial bank. However, FinTech companies as risky start-ups with low turnover but with the potential to become future competitors do not represent an attractive group of clients for commercial banks. Moreover, there appear to be problems of communication between FinTech companies and the regulator. The expectations of the regulator need clarification, as there are currently many uncertainties that lead to additional legal costs and extended product development cycle. This conclusion is in line with our assessment of the legal environment in Section 3.1. FinTech companies must obtain licenses from various regulatory bodies, and the rules are not always sufficiently clear, in particular for innovative products and services. Even 
though regulators offer some support and advice, FinTech companies see the current regulatory structure as a substantial obstacle.

Table 4. Responses to the question of which state organizations they communicate with on a regular basis.

\begin{tabular}{cc}
\hline Response Items & Number of Responses \\
\hline Predefined items & 12 \\
\hline State Revenue Service & 11 \\
\hline Binancial and Capital Market Commission & 1 \\
\hline Other responses & 9 \\
\hline PTAC/Consumer Rights Protection Center & 1 \\
\hline VARAM (Ministry of Environmental Protection and Regional \\
Development)
\end{tabular}

Companies also find that there is a shortage of local, highly skilled employees, which can be alleviated by reorienting training towards an IT specialty. Such effort, however, will take time. Another solution would be to hire foreign specialists. Given the relatively low salary level in Latvia compared to the EU, potential specialists would need to come from outside the EU. However, due to the rather strict immigration policy, it will be difficult to attract specialists from outside the EU. The FinTech companies' situation regarding attractiveness for skilled personnel is also reflected in our conclusions on the social environment as part of the PEST analysis. Latvia suffers from high brain drain, low wages in the service sector, and high effective personal income tax rate.

\section{Size and Financial Performance of FinTech Companies}

In this section, we analyse the 21 FinTech companies that responded to the survey to determine the latest trends in financial performance and size. Table 5 displays statistics for three size measures: number of employees (Panel A), turnover (Panel B), and total assets (Panel C). On average, the number of employees increases continuously between 2010 and 2017 and remains stable afterwards. Even though the average might be influenced by one relatively large company as reflected by the maximum number of employees in the sample, the median number of employees largely confirms the steady increase until 2017 and stable figures in 2018 and 2019. Moreover, from 2017 on, the number of companies in the sample is quite stable. 
Table 5. Size of FinTech companies.

\begin{tabular}{|c|c|c|c|c|c|c|c|c|c|c|}
\hline & 2010 & 2011 & 2012 & 2013 & 2014 & 2015 & 2016 & 2017 & 2018 & 2019 \\
\hline \multicolumn{11}{|c|}{ Panel A: Number of employees } \\
\hline Mean & 6 & 14 & 18 & 32 & 33 & 39 & 43 & 46 & 47 & 46 \\
\hline St. Dev. & 6 & 17 & 25 & 57 & 67 & 70 & 80 & 74 & 70 & 64 \\
\hline Median & 5 & 8 & 9 & 14 & 11 & 14 & 20 & 24 & 24 & 26 \\
\hline Min & 1 & 0 & 1 & 1 & 1 & 3 & 3 & 1 & 3 & 2 \\
\hline Max & 18 & 56 & 86 & 200 & 243 & 260 & 322 & 311 & 295 & 266 \\
\hline $\mathrm{N}$ & 6 & 8 & 9 & 10 & 11 & 12 & 14 & 15 & 15 & 16 \\
\hline \multicolumn{11}{|c|}{ Panel B: Turnover in thousand USD } \\
\hline Mean & 528 & 3953 & 7710 & 12,571 & 9773 & 9623 & 8306 & 8852 & 10,589 & 9213 \\
\hline St. Dev. & 266 & 6978 & 15,712 & 28,498 & 22,360 & 22,037 & 11,798 & 11,417 & 13,233 & 10,733 \\
\hline Median & 703 & 787 & 926 & 2698 & 1822 & 3078 & 1910 & 2586 & 5121 & 4069 \\
\hline Min & 105 & 103 & 82 & 89 & 247 & 3 & 1 & 8 & 32 & 101 \\
\hline Max & 761 & 20,920 & 48,959 & 92,909 & 76,504 & 85,168 & 39,230 & 36,770 & 42,509 & 30,354 \\
\hline $\mathrm{N}$ & 5 & 7 & 8 & 9 & 10 & 13 & 16 & 17 & 17 & 18 \\
\hline \multicolumn{11}{|c|}{ Panel C: Total assets in thousand USD } \\
\hline Mean & 776 & 4622 & 16,548 & 30,970 & 27,527 & 21,734 & 21,029 & 24,150 & 21,153 & 19,252 \\
\hline St. Dev. & 605 & 8122 & 40,316 & 76,071 & 78,379 & 51,725 & 42,655 & 46,834 & 36,511 & 30,893 \\
\hline Median & 585 & 1736 & 2141 & 2980 & 1675 & 3201 & 3450 & 4093 & 2549 & 3677 \\
\hline Min & 181 & 270 & 374 & 861 & 55 & 162 & 43 & 141 & 368 & 595 \\
\hline Max & 2050 & 25,912 & 130,451 & 245,895 & 297,402 & 204,791 & 176,417 & 195,143 & 149,172 & 124,631 \\
\hline $\mathrm{N}$ & 6 & 8 & 9 & 9 & 13 & 14 & 16 & 17 & 18 & 19 \\
\hline
\end{tabular}

Interestingly, however, the development of turnover and total assets is not completely in line with the increase in the number of employees. Turnover and total assets increase quite strongly between 2010 and 2013. Subsequently, turnover fluctuates around the 2013 level both in terms of mean and median values and only increases substantially again in 2018. Total assets fluctuate around the 2013 level until the end of the observation period in terms of median values, whereas mean values drop quite significantly between 2013 and 2015 and largely remain at the 2015 level until 2019. The latter effect seems to be driven by the largest company in the dataset as indicated by the development of the maximum value. The decline in turnover and total asset value can be attributed to several reasons. First, due to increased competition, borrowing interest rates have dropped significantly. While in 2010, the rates of some lending companies reached $400 \%$ per annum, maximum rates were about $50 \%$ per annum in 2014. Second, due to changes in the legislation to protect clients, several restrictions are imposed on lending companies, including the maximum interest rate, the penalty rate, and the maximum repayment amount. Third, in 2015 and 2016, two large new players in crowdfunding joined the market, hence increasing competition for lending companies. Fourth, the Latvian market is small; therefore, several large players significantly influence the overall statistics of the development of the FinTech industry.

Table 6 presents financial performance figures in terms of return on equity (RoE, Panel A) and profit margin (Panel B). Most striking is the huge variation in financial performance over time, as indicated by the development of mean and median values, and between companies, as indicated by standard deviation and minimum and maximum values. The relatively few FinTech companies that are included at the beginning of the observation period show quite high financial performance in 2010 and 2011. Financial performance drops, though, in 2012 and fluctuates around this level with quite substantial 
swings in until 2016 or 2017, depending on the measure. Only towards the end of the observation period, financial performance seems to improve, at least for some of the measures.

Table 6. Financial performance of FinTech companies.

\begin{tabular}{ccccccccccc}
\hline & $\mathbf{2 0 1 0}$ & $\mathbf{2 0 1 1}$ & $\mathbf{2 0 1 2}$ & $\mathbf{2 0 1 3}$ & $\mathbf{2 0 1 4}$ & $\mathbf{2 0 1 5}$ & $\mathbf{2 0 1 6}$ & $\mathbf{2 0 1 7}$ & $\mathbf{2 0 1 8}$ & $\mathbf{2 0 1 9}$ \\
\hline \multicolumn{7}{c}{ Panel A: Return on Equity in percent } \\
\hline Mean & 77.8 & 51.9 & 2.1 & 20.0 & 2.8 & -11.2 & 20.2 & 2.2 & 9.9 & 26.6 \\
\hline St. Dev. & 65.6 & 24.6 & 83.7 & 38.5 & 36.7 & 64.4 & 77.5 & 107.5 & 180.8 & 38.3 \\
\hline Median & 77.8 & 58.7 & 15.6 & 14.3 & 13.5 & -4.9 & 3.7 & 38.7 & 26.6 & 25.5 \\
\hline Min & 12.2 & 12.6 & -177.7 & -36.6 & -60.3 & -128.7 & -123.4 & -330.7 & -555.1 & -72.4 \\
\hline Max & 143.4 & 81.7 & 107.8 & 74.8 & 48.6 & 100.0 & 199.0 & 93.8 & 410.5 & 99.4 \\
\hline N & 2 & 5 & 8 & 8 & 11 & 11 & 11 & 12 & 15 & 14 \\
\hline & & & & Panel B: Profit margin in percent & & & \\
\hline Mean & 2.7 & 36.1 & 15.4 & 2.1 & 3.8 & 11.3 & 9.4 & 4.4 & 19.9 & 8.5 \\
\hline St. Dev. & 43.9 & 16.4 & 22.7 & 27.9 & 29.0 & 20.8 & 42.3 & 25.3 & 25.6 & 40.9 \\
\hline Median & 22.6 & 42.0 & 12.4 & 2.1 & 9.3 & 5.5 & 2.1 & 0.8 & 15.2 & 13.2 \\
\hline Min & -71.7 & 3.3 & -28.4 & -41.6 & -59.5 & -15.3 & -79.4 & -40.6 & -25.4 & -71.4 \\
\hline Max & 37.2 & 56.2 & 53.1 & 45.9 & 38.5 & 44.4 & 93.1 & 50.2 & 91.5 & 95.4 \\
\hline N & 4 & 7 & 7 & 9 & 8 & 10 & 12 & 13 & 14 & 16 \\
\hline
\end{tabular}

As indicated above, we need to interpret these results with caution. However, the huge variation over time and across companies indicates that, overall, the FinTech sector does not appear to have found a basis for stable business development and financial performance. Furthermore, the huge negative financial performance by some of the companies, as partially reflected by the minimum values, might indicate that some of the business models might not (yet) be financially sustainable. Reasons for this situation could be the strong dominance and competition between deposits and lending companies. The development of other activities, such as payment services, investment management, and insurance, has, though, the potential to open up new business opportunities.

\section{Discussion and Conclusions}

The purpose of this paper was to analyse the status quo, current developments, and challenges ahead for the Latvian FinTech sector. Our analysis has been divided into three parts: a PEST analysis to investigate the environment that Latvian FinTech companies are facing, an analysis of survey responses with particular emphasis on FinTech companies' own assessment of current and potential future developments, and an analysis of the financial performance of FinTech companies in Latvia during the last 10 years.

The results of the analysis of the political and legal, economic, social, and technological environment (PEST analysis) draws a mixed picture. The legal environment is largely predetermined by EU regulation, which also means that it is scattered across different types of financial services. Depending on the provided financial services, FinTech companies are regulated and monitored by the FCMC, the CRPC, or the State Revenue Service, since there is no legislation that comprehensively focuses on FinTech in Latvia. Instead, regulation that was established with focus on what nowadays are considered traditional financial services also applies to FinTech companies or no regulation exists yet for some of the new services. The overall economic environment can be considered positive, but Latvia still falls behind, e.g., its neighbours Estonia and Lithuania in quality and dynamics of the entrepreneurship ecosystems. Additionally, in the specific finance-related economic environment, Latvia should improve its situation. The social environment is favourable in particular with 
regard to level of skills and educational aspects as well as, e.g., labour market and female labour force. However, brain drain, remuneration in service professions, the labour tax rate, difficulties in hiring foreign labour, and, in general, difficulties in finding a skilled workforce raise substantial concerns. Even though Latvia does not reach top ranks when it comes to digital agenda and digital skills, its technological environment regarding, e.g., ICT adoption and electricity access is well developed.

The survey responses support the conclusions from the PEST analysis. For Latvian FinTech companies, regulation is the most pressing problem. This, however, is not a purely Latvian issue. Studies in neighbouring countries confirm that regulation represents a serious obstacle for FinTech development. In Poland, FinTech companies consider regulation ambiguous, imprecise, and requiring too much bureaucracy. They "[claim] that the rules are backward, neither follow the rapidly changing reality nor take the existence of the FinTechs into account" (Kliber et al. 2021). The same applies to Estonia, where the most critical problems are related to finding customers and to regulation (Laidroo et al. 2021b). Another result of the survey analysis is that the availability of a skilled staff or experienced managers is perceived as quite a pressing problem, which is, again, in line with the PEST analysis results. Further aspects, such as competition, finding customers, and access to finance, are perceived as pressing but to a lower degree than regulation and availability of skilled staff.

A result that is quite interesting in the context of the general idea of FinTech as disruption to the (traditional) finance industry, which is typically purported in the literature and in the public debate, is the survey respondents' view of integration of and collaboration between traditional banks and FinTech companies. FinTech is less perceived as disruptive but more as a driving force for innovation and modernization in the entire finance sector.

The size and financial performance of FinTech companies in Latvia during the last ten years indicates some difficulties when it comes to growth, and when it comes to establishing and maintaining business models that are financially sustainable. This is, of course, in line with the general situation in areas with high levels and speed of innovation. Not all business ideas become successful; some business will disappear, while new business models take over. However, when jointly looking at the results of the PEST analysis and the size and financial performance, the weaknesses that some of the aspects of the environment reveal seem to be significant obstacles for FinTech development.

In the context of our findings regarding regulation, it is no surprise that FinTech companies request specific FinTech regulation. The response to this request, however, requires some further considerations. On one hand, the absence of a legal framework that specifically focuses on FinTech might provide some additional comparative advantages to the FinTech market players compared to traditional financial service providers, at least in initial stages of development. On the other hand, and, in particular, in subsequent stages, this absence slows down the development of the market and the creation of a level playing field, both nationally and in the context of positioning Latvia as a FinTech hub internationally. More meaningful, however, both in the context of avoiding regulatory arbitrage of single market considerations and of increasing integration of FinTech solutions in more traditional financial service providers, is a revision, modernization, and harmonization of regulation, in particular across different categories of financial services, across different types of companies/institutions providing these services, irrespective of a higher or lower degree of involvement of new technologies, and internationally. Such a regulation would truly provide a level playing field and would foster competition.

In 2018, the Committee of Experts on the Evaluation of Anti-Money Laundering Measures and the Financing of Terrorism (MONEYVAL) granted Latvia supervisory status (Council of Europe 2019). As a result, supervision of the financial sector has been significantly strengthened, and Latvia has a much more detailed and rigorous approach to due diligence of clients than other countries, which creates a competitive disadvantage. Similarly, regulatory uncertainty is causing problems to FinTech companies looking to obtain an FCMC license to provide their service. Particular uncertainty exists regarding 
activities related to cryptocurrencies and other crypto assets. Additional regulation is often seen as an obstacle to the development of the sector. However, the thoughts on regulation presented above would not necessarily result in more regulation. Instead, a revision, modernization and harmonization might lead to less, or at least less complex, regulation. It requires though that the regulation needs to cover all financial services and should not leave blank spots for some of them. Currently, the FinTech industry needs to rely on the traditional banking industry, as, for example, all FinTech companies require a traditional bank account, as a result, making them dependent on banking policy.

It is worth mentioning, though, that Latvia's rigorous approach to strengthen its AML/CFT framework has proven fruitful and, according to the Financial Action Task Force Status (FATF), Latvia is not on the FATF List of Countries that have been identified as having strategic AML deficiencies (Financial Action Task Force 2021). This allows Latvia to think ahead and develop FinTech strategy, with an aim to identify and reduce any barriers to the growth of FinTech start-up companies. As the Latvian FinTech strategy is under development by a workgroup made up of the Ministry of Finance, the Financial and Capital Market Commission of Latvia, Fintech industry representatives, banks, the Investment and Development Agency of Latvia (LIAA), and various professional industry associations, our study provides contributions to the discussion and strategy development. Beyond regulation, the strategy development should particularly focus on further increasing the skill base and improving access to skilled employees, both nationally and internationally.

Our study is not without limitations. First, even though the response rate to our survey can be considered satisfactory, the survey respondents still only cover part of FinTech in Latvia. For future research and for the debate in the context of Latvian FinTech strategy development, it would be beneficial to include more FinTech companies. Second, we primarily focus on supply-side related drivers of FinTech development. To achieve a comprehensive understanding of drivers of FinTech development, the demand side also needs to be considered, regarding, e.g., consumers' and other customers' demand for FinTech solutions, their technology acceptance, financial and IT literacy, and individual characteristics of (potential and actual) users of FinTech services (Oehler et al. 2021).

Author Contributions: Conceptualization, R.R.-A. and S.W.; methodology, R.R.-A. and S.W.; formal analysis, R.R.-A. and S.W.; investigation, R.R.-A. and S.W.; data curation, R.R.-A.; writing-original draft preparation, R.R.-A. and S.W.; writing-review and editing, R.R.-A. and S.W.; visualization, R.R.-A. and S.W. All authors have read and agreed to the published version of the manuscript.

Funding: This research was funded by LATVIAN COUNCIL OF SCIENCE, grant number LZP2020/2-0061, project DigiSMEs.

Institutional Review Board Statement: Not applicable.

Informed Consent Statement: Not applicable.

Data Availability Statement: Data are available from authors upon reasonable request.

Acknowledgments: The survey used in this study is part of a larger European study of FinTech in Eastern Europe and we especially want to thank Laivi Laidroo (TalTech School of Business and Governance Department of Economics and Finance) for her help in developing the questionnaire. We are also grateful to Inna Romanova (University of Latvia) for her support in the survey implementation. We would like to thank all the companies who took part in the survey. We also would like to thank the head of the Alternative Financial Services Association of Latvia Gints Āboltinš for promoting the survey. We are grateful to all of those who have spared their time to read the preliminary version of the paper and give us valuable comments. While the first version of the paper was written, Stefan Wendt was at Reykjavik University, Iceland.

Conflicts of Interest: The authors declare no conflict of interest. 


\section{Notes}

1 The survey additionally included some questions on the financial situation of the companies and how they evaluate themselves vis à vis competitors. These questions were not considered for the further analysis though, because we decided to collect financial information on survey participants separately for a longer observation period.

2 Private pension funds are not further considered in the following descriptions due to relatively low relevance in the context of FinTech.

3 Beyond the regulatory situation described in this section, all financial service providers are subject to the Law on the Prevention of Money Laundering and Terrorism and Proliferation Financing (The Parliament of the Republic of Latvia 2008). The main institutions dedicated to combating money-laundering are the Financial Intelligence Unit of Latvia, FCMC, the State Revenue Service and CRPC.

4 Combined with potential free FCMC expert advice in PSD2, crowdfunding and/or virtual assets.

5 Application programming interface.

\section{References}

Ács, Zoltán J., Szerb László, Esteban Lafuente, and Markus Gábor. 2019. GEI_2019_Final-1. In Global Entrepreneurship Index. Washington, DC: Global Entrepreneurship and Development Institute, pp. 1-71. [CrossRef]

Ankenbrand, Thomas, Andreas Dietrich, and Denis Bieri. 2019. IFZ FinTech Study 2019 An Overview of Swiss FinTech. IFZ FinTech Study. Luzern: Institute of Financial Services Zug IFZ, p. 144.

Bank of Latvia. 2020. FINTECH Glossary. Available online: https:/ /www.bank.lv/en/publications-r/other-publications/fintechglossary (accessed on 15 June 2021).

Bureau van Dijk. 2021. Private Company Information-Orbis. Available online: https:/ /www.bvdinfo.com/en-gb/ (accessed on 17 June 2021).

Cabinet of Ministers. 2011. Regulations Regarding the Special Permit (Licence) for the Provision of Consumer Credit Services. Riga: Cabinet of Ministers.

Council of Europe. 2019. Anti-Money Laundering and Counter-Terrorist Financing Measures Latvia 1 St Enhanced Follow-Up Report (MONEYVAL). Strasbourg: Council of Europe.

Crunchbase. 2020. Discover Innovative Companies and the People behind Them. Available online: https://www.crunchbase.com/ (accessed on 24 June 2021).

European Union. 2009. Internet of Things: An Action Plan for Europe. In Communication from the Commission to the European Parliament, the Council, the European Economic and Social Committee and the Committee of the Regions. Maastricht: European Union.

FCMC. 2021a. FinTech Monitoring. Available online: https://www.fktk.lv/en/licensing/innovation-and-fintech/fintech-monitoring/ (accessed on 27 May 2021).

FCMC. 2021b. Regulatory Sandbox. Available online: https://www.fktk.lv/en/licensing/innovation-and-fintech/innovationsandbox/ (accessed on 27 May 2021).

Filimonova, Irina Viktorovna, Irina Viktorovna Provornaya, Anna V. Komarova, Ekaterina A. Zemnukhova, and Mikhail V. Mishenin. 2020. Influence of Economic Factors on the Environment in Countries with Different Levels of Development. Energy Reports 6: 27-31. [CrossRef]

Financial Action Task Force. 2021. Countries—Latvia. Available online: https://www.fatf-gafi.org/countries/\#Latvia (accessed on 22 June 2021).

Financial Stability Board. 2019. FinTech and Market Structure in Financial Services: Market Developments and Potential Financial Stability Implications_Financial Stability Board. Basel: Financial Stability Board.

Findexable. 2019. The Global Fintech Index 2020. London: Findexable.

FinTech Baltic. 2020. First Ever Latvia Fintech Startup Map Draft Released-Fintech in Baltic. January 27. Available online: https:/ / fintechbaltic.com/1575/fintechlatvia/latvia-fintech-startup-map-2020/ (accessed on 23 June 2021).

FinTech Baltic. 2021. Latvia Named Top Country with Largest Growth Fintech Interest Since 2020-Fintech in Baltic. Available online: https: / fintechbaltic.com/4707 / fintechlatvia/latvia-named-top-country-with-largest-growth-fintech-interest-since2020/ (accessed on 23 June 2021).

Gomber, Peter, Robert J. Kauffman, Chris Parker, and Bruce W. Weber. 2018. On the Fintech Revolution: Interpreting the Forces of Innovation, Disruption, and Transformation in Financial Services. Journal of Management Information Systems 35: 220-65. [CrossRef]

Hoque, Zahirul. 2004. A Contingency Model of the Association between Strategy, Environmental Uncertainty and Performance Measurement: Impact on Organizational Performance. International Business Review 13: 485-502. [CrossRef]

Horn, Matthias, Andreas Oehler, and Stefan Wendt. 2020. FinTech for Consumers and Retail Investors: Opportunities and Risks of Digital Payment and Investment Services. In Palgrave Studies in Sustainable Business in Association with Future Earth. Cham: Palgrave Macmillan, pp. 309-27. [CrossRef]

IMF. 2019. Fintech: The Experience So Far. IMF Policy Paper 77. Washington, DC: IMF.

Institute for Management Development. 2019. IMD World Talent Ranking 2019. Washington, DC: Institute for Management Development. 
Investment and Development Agency of Latvia. 2020. Areas of Activity. Available online: https://www.liaa.gov.lv/en/about-us / areas-activity (accessed on 19 June 2021).

Ito, Takatoshi, Kenta Yamada, Misako Takayasu, and Hideki Takayasu. 2020. Execution Risk and Arbitrage Opportunities in the Foreign Exchange Markets. Working Paper 26706. Cambridge: National Bureau of Economic Research. [CrossRef]

Key Capital. 2020. FinTech Companies in Latvia/Key Capital/Europe. Available online: https://www.keycapital.eu/ fintechcompaniesinlatvia (accessed on 15 May 2021).

Kliber, Agata, Barbara Będowska-Sójka, Aleksandra Rutkowska, and Katarzyna Świerczyńska. 2021. Triggers and Obstacles to the Development of the FinTech Sector in Poland. Risks 9: 30. [CrossRef]

Kluza, Krzysztof, Magdalena Ziolo, and Anna Spoz. 2021. Innovation and Environmental, Social, and Governance Factors Influencing Sustainable Business Models-Meta-Analysis. Journal of Cleaner Production 303: 127015. [CrossRef]

Laidroo, Laivi, Anneliis Tamre, Mari-Liis Kukk, Elina Tasa, and Mari Avarmaa. 2021a. FinTech Report Estonia 2021. Tallinn: Finance Estonia.EU. [CrossRef]

Laidroo, Laivi, Ekaterina Koroleva, Agata Kliber, Ramona Rupeika-Apoga, and Zana Grigaliuniene. 2021b. Business Models of FinTechs-Difference in Similarity? Electronic Commerce Research and Applications 46: 101034. [CrossRef]

Long Finance and Financial Centre Futures. 2020. The Global Financial Centres Index 28. London: Long Finance and Financial Centre Futures.

OECD. 2018. Financial Markets, Insurance and Private Pensions: Digitalisation and Finance. Paris: OECD.

Oehler, Andreas, and Stefan Wendt. 2018. Trust and Financial Services: The Impact of Increasing Digitalisation and the Financial Crisis. In The Return of Trust? Institutions and the Public after the Icelandic Financial Crisis. Bingley: Emerald Publishing Limited, pp. 195-211. [CrossRef]

Oehler, Andreas, Matthias Horn, and Stefan Wendt. 2021. Investor Characteristics and Their Impact on the Decision to Use a Robo-Advisor. Journal of Financial Services Research. forthcoming.

Olson, Eric M., and Stanley F. Slater. 2002. The Balanced Scorecard, Competitive Strategy, and Performance. Business Horizons 45: 11-16. [CrossRef]

Rikhardsson, Pall, Stefan Wendt, Auður Arna Arnardóttir, and Throstur Olaf Sigurjónsson. 2020. Is More Really Better? Performance Measure Variety and Environmental Uncertainty. International Journal of Productivity and Performance Management 70: 1446-69. [CrossRef]

Rupeika-Apoga, Ramona, and Eleftherios Thalassinos. 2020. Ideas for a Regulatory Definition of FinTech. International Journal of Economics and Business Administration 8: 136-54. [CrossRef]

Rupeika-Apoga, Ramona, and Roberts Nedovis. 2016. The Foreign Exchange Exposure of Domestic Companies in Eurozone: Case of the Baltic States. European Research Studies Journal 19: 165-78. [CrossRef]

Rupeika-Apoga, Ramona, and Svetlana Saksonova. 2018. SMEs' Alternative Financing: The Case of Latvia. European Research Studies Journal 21: 43-52. [CrossRef]

Saksonova, Svetlana, and Oksana Koleda. 2017. Evaluating the Interrelationship between Actions of Latvian Commercial Banks and Latvian Economic Growth. Procedia Engineering 178: 123-30. [CrossRef]

Saksonova, Svetlana. 2014. Foreign Direct Investment Attraction in the Baltic States. Journal: Business: Theory and Practice 15: 114-20. [CrossRef]

Sammut-Bonnici, Tanya, and David Galea. 2015. PEST Analysis. In Wiley Encyclopedia of Management. Hoboken: John Wiley \& Sons, Ltd. [CrossRef]

Solovjova, Irina, Ramona Rupeika-Apoga, and Inna Romānova. 2018. Competitiveness Enhancement of International Financial Centres. European Research Studies Journal 21: 5-17. [CrossRef]

Swedbank. 2020. Latvian Fintech Report 2020. Gothenburg: Swedbank.

The Alternative Financial Services Association of Latvia. 2021. Members. Available online: https://www.lafpa.lv/en/about-us/ members / (accessed on 12 July 2021).

The European Commission. 2018. FinTech Action Plan: For a more Competitive and Innovative European Financial Sector EN. Brussels: The European Commission.

The European Commission. 2019. Commission Delegated Regulation (EU) 2019/980. Official Journal of the European Union L 166/26. Available online: https:/ / eur-lex.europa.eu/legal-content/EN/TXT/?uri=CELEX\%3A32019R0980 (accessed on 12 July 2021).

The European Parliament and of the Council. 2014. Directive 2014/65/EU of the European Parliament and of the Council. Official Journal of the European Union L 173/349. Available online: http:/ / data.europa.eu/eli/dir/2014/65/oj (accessed on 12 July 2021).

The European Parliament and of the Council. 2015. Directive (EU) 2015/2366 of the European Parliament and of the Council of 25 November 2015 on Payment Services in the Internal Market, Amending Directives 2002/65/EC, 2009/110/EC and 2013/36/EU and Regulation (EU) No 1093/2010, and Repealing Directive 200. Official Journal of the European Union L 337/35. Available online: http:/ / data.europa.eu/eli/dir/2015/2366/oj (accessed on 12 July 2021).

The European Parliament and of the Council. 2018. Directive (EU) 2018/843 of the European Parliament and of the Council. Official Journal of the European Union L 156/43. Available online: http:/ / data.europa.eu/eli/dir/2018/843/oj (accessed on 12 July 2021). 
The European Parliament and of the Council. 2019a. DIRECTIVE (EU) 2019/2034 on the Prudential Supervision of Investment Firms and Amending Directives 2002/87/EC, 2009/65/EC, 2011/61/EU, 2013/36/EU, 2014/59/EU and 2014/65/EU. Official Journal of the European Union. Available online: https:/ / eur-lex.europa.eu/legal-content/EN/TXT/?uri=CELEX:32019L2034 (accessed on 19 July 2021).

The European Parliament and of the Council. 2019b. EUR-Lex-32019L2034-EN-EUR-Lex. Official Journal of the European Union L 314/64. Available online: http:/ / data.europa.eu/eli/dir/2019/2034/oj (accessed on 12 July 2021).

The European Parliament and of the Council. 2019c. REGULATION (EU) 2019/2033 on the Prudential Requirements of Investment Firms and Amending Regulations (EU) No 1093/2010, (EU) No 575/2013, (EU) No 600/2014 and (EU) No 806/2014. Official Journal of the European Union L 314/1. Available online: http:/ / data.europa.eu/eli/reg/2019/2033/oj (accessed on 15 July 2021).

The European Parliament and of the Council. 2020. REGULATION (EU) 2020/1503 of The European Parliament and of The Council of 7 October 2020 on European Crowdfunding Service Providers for Business. Official Journal of the European Union L $347 / 1$. Available online: http:/ / data.europa.eu/eli/reg/2020/1503/oj (accessed on 19 July 2021).

The European Parliament. 2017. Report on FinTech: The Influence of Technology on the Future of the Financial Sector (2016/2243(INI)). A8-0176/2017. Brussels: The European Parliament. [CrossRef]

The Financial and Capital Market Commission. 2002. Regulations on the Issue of Credit Institution and Credit Union Operating Licences. Riga: The Financial and Capital Market Commission.

The Parliament of the Republic of Latvia. 1997. Law on the Investment Management Companies. Riga: The Parliament of the Republic of Latvia.

The Parliament of the Republic of Latvia. 1999. Consumer Rights Protection Law. Riga: The Parliament of the Republic of Latvia.

The Parliament of the Republic of Latvia. 2000. Commercial Law. Riga: The Parliament of the Republic of Latvia.

The Parliament of the Republic of Latvia. 2001a. Credit Union Law. Riga: The Parliament of the Republic of Latvia.

The Parliament of the Republic of Latvia. 2001b. Investor Protection Law. Riga: The Parliament of the Republic of Latvia.

The Parliament of the Republic of Latvia. 2003. Law on the Financial Instruments Market. Riga: The Parliament of the Republic of Latvia.

The Parliament of the Republic of Latvia. 2004. Compulsory Civil Liability Insurance of Owners of Motor Vehicles Law. Riga: The Parliament of the Republic of Latvia.

The Parliament of the Republic of Latvia. 2008. The Law on the Prevention of Money Laundering and Terrorism and Proliferation Financing. Riga: Latvijas Vestnesis.

The Parliament of the Republic of Latvia. 2010. The Law on Payment Services and Electronic Money. Riga: The Parliament of the Republic of Latvia.

The Parliament of the Republic of Latvia. 2013. Law on Alternative Investment Funds and Their Managers. Riga: The Parliament of the Republic of Latvia.

The Parliament of the Republic of Latvia. 2015a. Deposit Guarantee Law. Riga: The Parliament of the Republic of Latvia.

The Parliament of the Republic of Latvia. 2015b. Law on Insurance and Reinsurance. Riga: The Parliament of the Republic of Latvia.

The Parliament of the Republic of Latvia. 2017. Law on the Recovery and Resolution of Credit Institutions and Investment Firms. Riga: The Parliament of the Republic of Latvia.

The Parliament of the Republic of Latvia. 2018. The Insurance Contract Law. Riga: The Parliament of the Republic of Latvia.

The Parliament of the Republic of Latvia. 2019. The Insurance and Reinsurance Distribution Law. Riga: The Parliament of the Republic of Latvia.

Tirmaste, Kersti, Liina Voolma, Laivi Laidroo, Mari-Liis Kukk, and Mari Avarmaa. 2019. FinTech Report Estonia 2019. Tallinn: Finance Estonia.EU. [CrossRef]

World Bank Group. 2020. Doing Business 2020: Comparing Business Regulation in 190 Economies. Washington, DC: World Bank Group. [CrossRef]

World Economic Forum. 2019. The Global Competitiveness Report 2019. Cologny: World Economic Forum. [CrossRef]

World Economic Forum. 2020. The Europe 2020 Competitiveness Report: Building a More Competitive Europe. Cologny: World Economic Forum.

Yeandle, Mark, and Michael Mainelli. 2015. The Global Financial Centres Index 17. The Global Finance Centres Index (GFCI)—Long Finance, 2015. Available online: https:/ / ssrn.com/abstract=3671501 (accessed on 9 July 2021). 